\title{
Abbreviations and Editor's Remarks
}

$B E A=$ Breve og Aktstykker vedrorende Søren Kierkegaard [Letters and Documents Pertaining to Søren Kierkegaard], I-II, ed. Niels Thulstrup (Copenhagen: Munksgaard, 1953-54)

KBHA = Det kongelige Bibliotek, Håndskriftafdeling [Manuscript Department of the Royal Library (Copenhagen)]

$K W=$ Kierkegaard's Writings, I-XXVI, ed. Howard V. Hong (Princeton: Princeton University Press, I978-). I9 vols. published as of September 1995 NBD $=$ Nyere Brevsamling Dansk [New Collection of Danish Letters] in the Manuscript Department of the Royal Library (Copenhagen)

NkS $=$ Ny kongelige Samling [New Royal Collection] in the Manuscript Department of the Royal Library (Copenhagen)

Pap. = Soren Kierkegaards Papirer [The Papers of Søren Kierkegaard], I-XVI, ed.

P. A. Heiberg, V. Kuhr, and E. Torsting; 2d augmented ed., ed. Niels Thulstrup; index by N. J. Cappelørn (Copenhagen: Gyldendal, 1968-78)

RA = Rigsarkivet [National Archives] (Copenhagen)

SKA = Søren Kierkegaard Arkiv [Søren Kierkegaard Archive] in the Manuscript Department of the Royal Library (Copenhagen)

SKEP $=$ Af Soren Kierkegaards Efterladte Papirer [From the Posthumous Papers of Søren Kierkegaard], I-VIII, ed. H. P. Barfod and H. Gottsched (Copenhagen: Reitzel, I869-8I)

SKJP = Soren Kierkegaard's Journals and Papers, I-VII, ed. and trans. Howard V.

Hong and Edna H. Hong (Bloomington, Indiana: I967-78)

$S V=$ Soren Kierkegaards Samlede Varker [The Collected Works of Søren Kierkegaard], I-XIV, Ist ed., ed. A. B. Drachmann, J. L. Heiberg, and H. O. Lange (Copenhagen: Gyldendal, I90 I-6)

Italic type has been employed to represent all forms of emphasis in the original text, for the titles of published works, and for Latin, French, and German words and phrases.

Square brackets have been employed to indicate editorial additions to the original text and for dates and other components of letters and journal entries.

All footnotes in this volume also appear as footnotes in the original source materials. All explanatory notes by the editor are printed as endnotes, which are grouped and numbered by chapter at the end of the volume. Each entry is accompanied by a numbered endnote, which begins with source information for that entry and which often will also include explanations of various details 
in that entry; the details explained in each entry are highlighted in boldface type in the endnote.

In the nineteenth century, standardized spelling had not yet been introduced in the Danish language, and the name "Søren Aabye Kierkegaard" was thus spelled and abbreviated in many different ways. These variants have been retained in the present volume in order to preserve some of the flavor of the original documents. 